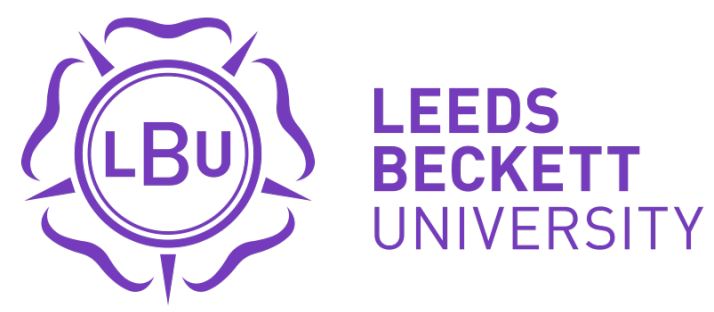

Citation:

Alaka, HA and Oyedele, LO and Owolabi, HA and Bilal, M and Ajayi, SO and Akinade, OO (2017) Insolvency of Small Civil Engineering Firms: An Examination of Critical Strategic Factors. Journal of Professional Issues in Engineering Education and Practice. ISSN 1943-5541 DOI: https://doi.org/10.1061/(ASCE)El.1943-5541.0000321

Link to Leeds Beckett Repository record:

https://eprints.leedsbeckett.ac.uk/id/eprint/3217/

Document Version:

Article (Accepted Version)

The aim of the Leeds Beckett Repository is to provide open access to our research, as required by funder policies and permitted by publishers and copyright law.

The Leeds Beckett repository holds a wide range of publications, each of which has been checked for copyright and the relevant embargo period has been applied by the Research Services team.

We operate on a standard take-down policy. If you are the author or publisher of an output and you would like it removed from the repository, please contact us and we will investigate on a case-by-case basis.

Each thesis in the repository has been cleared where necessary by the author for third party copyright. If you would like a thesis to be removed from the repository or believe there is an issue with copyright, please contact us on openaccess@leedsbeckett.ac.uk and we will investigate on a case-by-case basis. 


\section{Insolvency of Small Civil Engineering Firms: An Examination of Critical Strategic Factors}

Hafiz A. Alaka ${ }^{1}$, Lukumon O. Oyedele ${ }^{2}$, Hakeem A. Owolabi ${ }^{3}$, Muhammad Bilal $^{4}$, Saheed O. Ajayi $^{5}$, and Olugbenga O. Akinade ${ }^{6}$.

${ }^{1}$ Doctoral Researcher. Bristol Enterprise Research and Innovation Centre, University of the West of England, Bristol, United Kingdom. Room 4B02, Bristol Enterprise Research and Innovation Centre, Frenchay Campus, University of the West of England, Bristol, United Kingdom. hafiz2.alaka@live.uwe.ac.uk

${ }^{2}$ Professor. Bristol Enterprise Research and Innovation Centre, University of the West of England, Bristol, United Kingdom (corresponding author). Room 3FC076, Felix Stowe Court, Bristol Enterprise Research and Innovation Centre, University of the West of England, Bristol, United Kingdom. L.Oyedele@uwe.ac.uk

${ }^{3}$ Doctoral Researcher. Bristol Enterprise Research and Innovation Centre, University of the West of England, Bristol, United Kingdom. Room 4B02, Bristol Enterprise Research and Innovation Centre, Frenchay Campus, University of the West of England, Bristol, United Kingdom. hakeem2.owolabi@live.uwe.ac.uk

${ }^{4}$ Doctoral Researcher. Bristol Enterprise Research and Innovation Centre, University of the West of England, Bristol, United Kingdom. Room 4C14, Bristol Enterprise Research and Innovation Centre, Frenchay Campus, University of the West of England, Bristol, United Kingdom.muhammad2.bilal@live.uwe.ac.uk

${ }^{5}$ Doctoral Researcher. Bristol Enterprise Research and Innovation Centre, University of the West of England, Bristol, United Kingdom. Room 4C14, Bristol Enterprise Research and Innovation Centre, Frenchay Campus, University of the West of England, Bristol, United Kingdom. saheed2.ajayi@live.uwe.ac.uk

${ }^{6}$ Doctoral Researcher. Bristol Enterprise Research and Innovation Centre, University of the West of England, Bristol, United Kingdom. Room 4C14, Bristol Enterprise Research and Innovation Centre, Frenchay Campus, University of the West of England, Bristol, United Kingdom. olugbenga2.akinade@live.uwe.ac.uk

\section{Abstract}

Construction industry insolvency studies have failed to stem the industry's high insolvency tide because many focus on big civil engineering firms (CEF) when over $90 \%$ firms in the industry are small or micro (S\&M). This study thus set out to uncover insolvency criteria of S\&M CEFs and the underlying factors using mixed methods. Using convenience sampling, storytelling 
method was used to execute interviews of 16 respondents from insolvent firms. Narrative and thematic analysis were used to extract 17 criteria under 2 groups. Criteria were used to formulate questionnaire of which 81 completed copies were received and analysed using Cronbach's alpha coefficient and relevance index score for reliability and ranking respectively. The five most relevant criteria are: economic recession, immigration, too many new firms springing up, collecting receivables and burden of sustainable construction. The 4 underlying factors established through factor analysis are: market forces, competence-based management, operations efficiency and other management issues and information management. The factors were in line with Mintzberg's and Porters' strategy theories. Results demonstrate that insolvency factors affecting big and small CEF can be quite different and sometimes, even opposite. This research will provide a unique resource on the 'beware' factors for potential owners of S\&M CEF. The criteria are potential variables for insolvency prediction models for S\&M CEFs.

Key words: Civil engineering firms, construction industry, small and micro firms, insolvency, mixed method

\subsection{Introduction}

While research in construction has focused more on green sustainability in terms of reducing resource consumption and construction waste, the construction industry has been more troubled with economic sustainability in terms of solvency of firms. For instance, over 1500 civil engineering firms became insolvent at the beginning of 2012 alone (Daily Mail Reporter, 2012). To contextualise this better, though the overall insolvency in the UK in the second quarter of 2015 was its lowest since 2007 , the construction industry still led the liquidated companies in England and Wales chart at the end of the same period (Wood, 2015), a position it has held over 
many years (Department for Business Innovation and Skills, 2015). This is so, despite a lot of research into the reason for failure of civil engineering firms.

So why have the many studies on civil engineering firms' failure not really helped to stem the insolvency tide? It is partly because most construction industry insolvency studies have focused on big civil engineering firms when the majority of the firms that have become insolvent are small, reflecting not just the highly skewed distribution of firm size in the sector, but also the strong negative correlation of incidence of failure with size. The skewed distribution is clear from the industry statistics: the industry boasted over 950,000 small and medium enterprise (SME) in 2015; the industry represents circa $20 \%$ of the UK private sector SMEs, making it the sector with the highest percentage of SME firms (Department for Business Innovation and Skills, 2015); over $96 \%$ of UK civil engineering firms as of 2001 are small or micro firms (Jaunzens, 2001); and 86\% of employees in the sector work in small civil engineering firms (Stanworth and Purdy, 2008). It is thus nigh on impossible to stem the high rate of insolvency in the industry without doing more research on failure of small civil engineering firms. According to the European Union definition of firm sizes, micro firms are firms with one to nine employees and with a turnover equal to or less than two million Euros; small firms are those with 10 to 49 employees and with a turnover equal to or less than 10 million Euros; medium-sized firms are firms with 50 to 249 employees and with a turnover equal to or less than 50 million Euros; large firms are those with over 250 employees and with a turnover of more than 50 million Euros.

A major size related problem with research on failure of civil engineering firms is that most studies that attempt to build insolvency prediction models tend to rely mainly on financial statements of the sample firms (e.g. Abidali and Harris, 1995; Chen, 2012; Bal et al., 2013; and more). This method, in more ways than one, does not really help the small or micro firms 
(Balcaen and Ooghe, 2006). One way is that the studies normally exclude incomplete accounting data which is a popular feature of small and micro firms (Balcaen and Ooghe, 2006). Another way is that many small and micro firms outsource financial statement production with the main aim of meeting the legal requirement of annual production. This easily breeds misrepresenting statements since they are based solely on the amount of, intentionally or unintentionally but usually, incomplete information provided to the accounting firm producing the statement. This method thus has little implication on helping the solvency situation of small and micro civil engineering firms

Accordingly, the aim of this study is to uncover the main strategic factors that lead to insolvency of small and micro civil engineering firms. The objectives are:

To inductively identify criteria that lead to the insolvency of small and micro civil engineering firms through qualitative methods

To deductively establish the relevance of each of the identified criteria and establish the underlying factors through quantitative methods

This study will contribute to knowledge by exposing the key factors that lead to failure of small and micro civil engineering firms. The difficulty of locating and subsequently getting access to owners of failed firms is well acknowledged in the research world (Stokes and Blackburn 2002; Harada 2007) hence the qualitative method in this study, which will be executed using storytelling, provides a unique resource. The scope of this work is limited to factors affecting small and micro civil engineering firms only; medium and large firms will not be considered. The civil engineering firms considered in this study are those classified by the UK Standard industrial classification of economic activities (SIC) 2007 as 41100 Development of building projects; 41201 Construction of commercial buildings; 42110 Construction of roads and motorways; 42120 Construction of railways and underground railways; 41202 Construction of 
domestic buildings; 42130 Construction of bridges and tunnels; 42210 Construction of utility projects for fluids; 42220 Construction of utility projects for electricity and telecommunications; 42910 Construction of water projects; 42990 Construction of other civil engineering projects n.e.c.; 43110 Demolition; and 43120 Site preparation. It does not involve 43130 Test drilling and boring; 43210 Electrical installations; 43220 Plumbing, heat and airconditioning installation; 43290 Other construction installation; 43310 Plastering; 43320 Joinery installation etc.

The next section describes the theoretical background to this work: mainly Mintzberg's five Ps of strategy and Porter's five competitive forces. This is followed by the methodology section which explains the qualitative method executed with storytelling and the quantitative method executed with the survey strategy. Section four explains the thematic and narrative methods used to analyse qualitative data, and the reliability, relevance index score and factor analysis used to analyse quantitative data. Section five provides discussion on the established underlying factors. The paper is then rounded up with the conclusion section.

\subsection{Theoretical Background}

Given the multifaceted nature of insolvency and that no individual criteria can answer what determines insolvency of a firm, there are numerous contending theories attempting to reveal what helps to improve solvency (i.e. to avoid insolvency), especial through strategy. Many theories on what strategy to use to aid solvency have been developed over the years. The theories of strategy are quite variant and are not necessarily mutually exclusive; most of them having different emphasis. The diverse and complex nature of strategy was attested to by Mintzberg et al. (1998). After reviewing ten strategy models, they concluded that "strategy formation is judgmental designing, intuitive visioning, and emergent learning; it is 
about transformation as well as perpetuation; it must involve individual cognition and social interaction, cooperation as well as conflict; it has to include analysing before and programming after as well as negotiating during; and all of this must be in response to what can be a demanding environment. Just try and leave any of this out and see what happens" (Mintzberg, 1998, pp 372-373). The two most important and relevant strategic theories according to Moore (2011) are Mintzberg's and Porter's.

Mintzberg Perspective: The Mintzberg's perspective is famous as it took a holistic and integrated approach to various strategy theories to develop what is known as the five Ps (plan, ploy, pattern, position and perspective). It has been the basis for some strategy research in construction (e.g. Chinowsky and Meredith, 2000; Dikmen and Birgönül, 2003). A strategy is more or less in itself regarded as a plan. Planning is the most popular and is virtually the default approach by managers. It is usually based on information hence having poor information can lead to poor strategy as plan. Ploy strategy mainly has to do with making a ploy to outwit competitors while pattern is about the decision a firm takes over time which then becomes the firm's way of doing things (Simon, 1957). According to Mintzberg (1998), it is the actions that a firm takes, and not the decisions, that lead to patterns; this is because the interconnection between decision making and actions in a firm is usually unclear. Generally, there is often a great deal of action with little decisions, and sometimes vice versa. Further, the actions and decisions are sometimes uncorrelated. According to Andrews (1971), the essence of strategy is pattern. Strategy as position refers to positioning a firm in such a way that it stands out from others. This is very much about being unique. In the non-product based construction industry, uniqueness is usually about method of execution and this is normally dependent on the resources at the disposal of the firm (Korn and Pine, 2014). Perspective as strategy refers to the fact that the ways of thinking in a firm will largely influence the strategy the firm adopts. For 
example, a firms that encourages caution in resource consumption and waste generation is likely to have employees come up with more sustainable solutions.

Porter's perspective: The Porter's perspective is famous for the five competitive forces model: supplier power, buyer power, competitive rivalry, threat of substitution and threat of new entry. According to Rumelt et al. (1991, p.8), "the most influential contribution of the decade from economics was undoubtedly Porter's competitive strategy (1980)". It has been the basis for some strategy research in construction (e.g. Betts and Ofori, 1992, 1993; Budayan et al., 2013; Tansey et al., 2014). The threat of new entrant remains one of the most applicable forces to the construction industry as entrance to the industry has no barrier and sometimes require little investment (Betts and Ofori, 1992). This is unlike some other industries like the computing and engineering industries in Japan where huge investments by larger companies is proving to be a barrier to entrance for potential smaller companies. Supplier power wise, there are usually many suppliers in the construction industry however, keeping a good relationship with a small set of specific suppliers, thereby buying in high volumes from them could give a competitive advantage. This is because being a major buyer allows the firm to drive down prices of the supplier. It also ensures the firm is given priority when there is materials shortage. The threat of substitution refers to how easy it is for a client to replace one firm with the other. This threat is usually high in the construction industry as there are always too many firms competing for one job, hence being unique can give a competitive advantage here. Competitive rivalry, which is the fifth force, is the same as Mintzberg's strategy as position in that it is all about firms vying for a better/unique position to give them competitive advantage. According to Betts and Ofori (1992), vying for position is a strong competitive force among small construction firms despite the low exit barrier of the industry. 


\subsection{Methodology}

\subsection{Qualitative Method}

One issue common with investigation of failures is the use of financial statements which most small firms either do not have, or do not possess accurate ones. In fact, some firms go into insolvency in their first two years before the UK legally required time to produce their first statement. Another issue is that when a subjective approach is taken, the subjects are usually asked for their views when some of them cannot judge best what some key problems were and have repeatedly failed with subsequently established firms. Those unidentified key problems are referred to as the deeper truths which are unattainable with direct observation; a viewpoint rejected by positivism and empiricism but well accepted by structuralism, hermeneutics and psychoanalysis (Gabriel and Griffiths 2004). On using the subjective approach to search for the deeper truth, it is usually onerous to detach the more or less important insolvency criteria by respondents in research. Ordinarily, the owner, manager, employee etc. of a failed firm is more tilted to blaming other stakeholders although, such blames are sometimes true. This study will hence elucidate the complex process of failure of small and micro civil engineering firms by analysing the 'stories' of mainly owners, and sometimes managers and employees of such firms. This is done by listening to their accounts of the life of the civil engineering firm from establishment (or stage of involvement) to insolvency. By using the story telling method, the researchers prevent any form of priori assumptions about the criteria that lead to insolvency but can conduct a narrative analysis of the stories to identify what events, actions, or occasions contributed to insolvency. Storytelling can be of unstructured interview as in this study, and/or semi structured in other cases (Gabriel and Griffiths 2004). 
The owners/employees of insolvent civil engineering firms were contacted in two major ways. First was to use the FAME (Forecasting Analysis and Modelling Environment) Bureau Van Dijk UK financial database to identify failed civil engineering firms' directors, and subsequently identify existing firms where those directors currently work. Fifty identified directors were subsequently contacted and a request for an interview was made. Most of the directors unsurprisingly turned out to be the owner of the firms, a common feature of small and micro firms. The second was to use the position of one of the authors as a college lecturer that taught on construction apprentice programmes. The apprentices were persuaded to talk to colleagues and/or bosses at work in order to identify those that have worked in, managed or owned a now defunct construction firm. Some apprentices were, by themselves, suitable respondents as they once owned firms and most agreed to respond positively to the request of talking to colleagues and/or bosses. This method of sampling is known as convenience sampling and has been used in a number of construction studies (e.g. Li et al., 2005; Oyedele, 2013). This sampling method became necessary because of the inherent difficulty in finding stakeholders of insolvent construction firms. A total of 18 respondents agreed to take the interview. Table 1 presents the demographics of the respondents and the firms. Since insolvent firms are virtually impossible to trace because of their non-functioning-anymore contacts (Everett and Watson 1998; Stokes and Blackburn 2002; Harada 2007), the interviews/stories from this research will supply a unique resource.

\section{Table 1: Demographics of the respondents and the firms}

The questions used in the interviews were designed such that they were unrestricting in order to avoid pre-determined responses, and to evoke stories about how the firm's failure came about. Although it was referred to as being in its infancy stage in 2004 (Gabriel and Griffiths, 2004), the storytelling method is now a widely accepted and used method (see for example 
Steyaert and Bouwen 1997; Hill and McGowan 1999; Rae 2000; Marcella and Illingworth, 2012 among others). In fact, Denning (2005) emphasized that research that does not value storytelling as a way of understanding firm performance cannot give a complete account of that firm.

Storytelling or narratives are taken to be especially valuable and appropriate when researching sensitive topics such as insolvency of firms (Marcella and Illingworth, 2012). Insolvency can be a bad experience for some owners which they do not want to recall or discuss it. Extra effort was thus made to make the questions as non-judgemental as possible.

More time was spent with respondents that delivered many/longer stories as required when the stories, as against the story tellers, are the unit of analysis (Gabriel and Griffiths 2004) as is the case in this study. Incidents that related to insolvency or firm problems were explored further after the stories by seeking elicit accounts of the incidents through direct or indirect tactic; this is appropriate for the storytelling method according to Gabriel and Griffiths (2004).

The stories elicited from the respondents can be categorized as tragic considering the four categories of stories (comic, epic, tragic and romantic) presented by Gabriel and Griffiths (2004). This is not too surprising as many of the respondents were owners of insolvent construction firms and were not happy about the insolvency. Some stories however sounded epic, or a combination of tragedy and epic, as the respondents tried more to show how they made mistakes and learned from them and then defiantly started (or are willing to start) another firm which is now (will be) a success 


\subsection{Quantitative Method}

The themes that resulted from analysing the qualitative data were used to develop a preliminary questionnaire to determine how relevant each identified criteria is to determining solvency/insolvency of small civil engineering firms. A Likert scale of one to five was used where five represents 'most relevant' and one represents 'least relevant'. This preliminary questionnaire was used as a pilot study with the aim of evaluating its relevance/correctness, complexity, length and layout before being sent out to a wider set of target respondents.

The sampling strategies used for the qualitative study were repeated but extended to reach more potential respondents. After a very onerous search, an extra 250 directors of failed civil engineering firms working in existing firms were identified from FAME Bureau Van Dijk and the questionnaires were sent to them. This was done via post and/or email. In the second strategy the author in the position of a college lecturer successfully contacted some other lecturers, from five different colleges, teaching on civil engineering apprentice programmes (year one and two) and the questionnaires were given to all the students to pass on to potential respondents. This was done mainly by giving the students copies of the questionnaire. The number given to each student was determined by the student, based on how many potential respondents the student thinks he has access to. In all, over 500 questionnaires were sent out.

A total of $84(16.8 \%)$ questionnaires were returned after several reminders. Three out of these 84 were incomplete and unusable, leaving only 81 (16.2\%) usable questionnaires for the quantitative analysis. Of the usable questionnaires, circa $88.9 \%$ were from former owners of civil engineering firms while the rest were from former managerial level staff of civil engineering firms. The questionnaire data was analysed using Statistical Package for Social Sciences (SPSS) software. 


\subsection{Analysis of Data and Results}

\subsection{Qualitative Data Analysis}

There are a number of approaches to analysing qualitative data, each approach stemming from different traditions. This study used the narrative and thematic qualitative analyses to analyse the obtained data. The narrative analysis, which is the usually employed technique for story telling was used first, but in a secondary manner (Saunders et al., 2009). In analysing and interpreting each respondent's stories, the transcripts were carefully read and each one was disaggregated into a number of recognizable insolvency episodes (Shotter, 1993).

In order to satisfy one of the objectives of the study of identifying the criteria affecting failure of small construction firms, thematic analysis was subsequently performed on all the episodes (Saunders et al., 2009) using the Nvivo software. Both prior categories and new categories were used and developed respectively during the thematic analysis. Prior categories were taken from the general construction firms' insolvency studies while any issue identified during reading through the episodes were also used to construct conceptual categories which characterised major themes. The Nvivo software word frequency search was also used to create themes. Example of coding from priori and new themes and the respondents' statements they are taken from are presented in Table 2.

Table 2: Example of coding from priori and new themes and the respondents' statements they are taken from

The transcripts were read repeatedly and discussed between the authors in relation to both prior and newly constructed categories. Extra effort was made to maintain awareness of the effect of research process on the stories obtained during the interpretation and analysis of obtained data. It is acknowledged that many components of the research process such as respondent's talkative 
ability, command of interview/story language (i.e. English language), level of experience, social class, etc. may have had effect on the eventual output. The findings are thus taken to be a construction process between the researchers and the respondents, as not representing a single truth, but instead as some possible stories of many potential stories. The criteria gotten from the findings are organized into two groups: internal and external related criteria. These criteria are presented in Table 3.

\subsection{Quantitative Data Analysis}

\subsubsection{Reliability analysis}

As recommended by many social scientists (Spector, 1992; George and Mallery, 2003; Field, 2005; Nunnally and Bernstein, 2007 among others), this study used the Cronbach's alpha coefficient test to examine the reliability of the questionnaire data. Mathematically, Cronbach's alpha is written as

$$
\alpha=\frac{\mathrm{N}^{2} \overline{\mathrm{COV}}}{\sum \mathrm{S}_{\text {criteria }}+\sum \mathrm{COV}_{\text {criteria }}}
$$

The goal of the test was to check the consistency in the obtained data in order to establish if the criteria and their associated Likert scale are really measuring the construct they were intended to measure (Field, 2005). The construct in this case is the relevance of the identified criteria to determining failure/survival of small civil engineering firms. Cronbach's alpha coefficient value ranges from 0 to 1 and as a thumb rule, 0.7 is suggested as the lowest acceptable score and 0.8 as an indication of good internal consistency, 0.9 and above represent high consistency (George and Mallery, 2003). Table 3 presents the Cronbach's alpha coefficient test results gotten from SPSS. The reliability test was ran and the overall Cronbach's alpha coefficient gotten was 0.868 , depicting good internal consistency of the data. 


\section{Table 3: The final 17 insolvency criteria and associated statistical analysis.}

To check if all the criteria are contributing to the internal consistency of the data, the 'Cronbach's alpha if item deleted', located in column three of Table 3 is further investigated. A criterion that is not contributing to the overall reliability of the data will normally have a higher associated 'Cronbach's alpha if item deleted' value than the data's overall coefficient (Field 2005). This higher value depicts that if the criteria with the value is deleted, the overall reliability of the data will increase (Field 2005). In this context, only IC12 (0.870) has a 'Cronbach's alpha if item deleted' value which is greater than the overall coefficient $(0.868)$. This implies that this criteria - 'fluctuation of construction materials cost'- is relatively not a very good measure of the construct hence it was not considered.

\subsubsection{Insolvency Criteria Relevance Index and Ranking}

To estimate the respondents' perception of the relevance of each of the criteria, an insolvency criteria relevance index score was calculated using the equation below. The equation was derived from comparable formula deduced by authors of previous construction studies (e.g. Kometa et al., 1994; Oyedele, 2013). Insolvency criteria relevance index (ICFI) is

$$
\text { ICRI }=\left[\begin{array}{c}
N \\
\sum_{n=1}\left(R_{n}\right) \\
\hline N G
\end{array}\right] \times 100 \% \quad--------------(\text { equation 2) }
$$

where $\mathrm{R}$ is the relevance rating given by the (ith) respondent ranging from 1 to $5 ; \mathrm{i}=1,2,3$, 4..... N; $\mathrm{N}$ is the total number of respondents for that particular criteria; and $\mathrm{G}$ is the highest relevance point i.e. 5. The last three columns of Table 3 present the IRFI scores, the in-group rankings and the overall rankings of the criteria. Excluding the criteria with unreliable data (i.e. IC12: fluctuation of construction materials cost), the top five relevant criteria are: IC11 - 
‘economic recession', IC13 - ‘immigration', IC14 - 'too many new firms springing up', IC1 'collecting receivables' and IC15 - 'burden of sustainable construction practice', in that order. It is not surprising that economic recession was voted to be the most relevant as there was one in as recent as between 2007 and 2009; and it would have been a major contributing factor to the insolvency of some respondents' firms. The main challenge a recession brings is the reduced number of projects/contracts available in the market, leading to a much higher contractor/project ratio. The results are discussed further in the next section.

\subsubsection{Factor Analysis}

To achieve another objective of this study, there is need to establish the main underlying factors that form the basis of the identified criteria. This will cause the numerous identified criteria to be replaced with few, more concise and uncorrelated principal factors. For the explorative factor analysis using the SPSS software, principal component analysis and varimax were used as methods of factor extraction and rotation respectively. During the process, Bartlett tests of sphericity and Kaiser-Meyer-Olkin (KMO) measure of sampling adequacy were also conducted to check the appropriateness of the data for factor analysis. Values of 0.76 (above 0.5) and 0.0001136 (less than 0.05) were gotten respectively, demonstrating that the data set is suitable for factor analysis (Pallant, 2005). In interpreting the results, all factors with Eigen value of one and above were retained, while criteria with factor loading of +0.3 and above or -0.3 and below were taken as part of the offspring of their principal factor (Child, 2006). The output of the analysis was of four factors which represented $73.349 \%$ of total variance as presented in Table

4. The factors were named according to the offspring criteria as follows:

Market forces

Competence-based management

Operations efficiency and other management issues 
Information management

From the factor analysis result in Table 4, although IC12 was categorized under the market forces factor, it was not considered as it did not satisfy the reliability test from section 4.2.1. Under operations efficiency and other management issues and information management factors, the IC5- outsourcing account management (0.201) and IC9-over reliance on account statement (0.273) respectively have factor loadings below 0.3 hence cannot be strongly considered as offspring of their principal factors. They are thus not considered under the affected factors.

\section{Table 4: Exploratory factor analysis.}

\subsection{Discussion}

This section discusses the identified underlying factors from factor analysis in terms of the constituting criteria. The interest is mainly in the top ranked criteria, according to the ICRI score, under each factor. Note that in Table 4, the criteria are arranged under each factor according to their position from the ICRI score. Because the market forces factor contains four of the five overall most relevant criteria in terms of ranking, it is widely discussed with an attempt to capture most criteria under it. Only the top two criteria are discussed in the other three factors.

Market forces: A major problem small civil engineering firms have with market forces is that they have absolutely no control over them. This forces the strategic conflict theory into play where firms turn to outwitting other firms in order to survive (Shapiro, 1989). The theory assumes common interest between adversaries (civil engineering firms in this case) and that every party's best choice of action is completely dependent on what is expected of other players (Schelling, 1963). Small civil engineering firms hence focus more on threats or potential threats 
of losing bids to other similar firms for example. They will want to deter competitors or outdo them.

Of all the highlighted market forces, 'economic recession' is probably the most severe as identified by respondents and in other studies (e.g. Kangari, 1988; Arditi, et al., 2000; Kapliński, 2008; Thomas et al., 2011; Sang et al., 2013). Although it does not happen too frequently its effect, when it does, can be devastating. Virtually everyone in the country is hit somehow and plans for new build, renovations, expansions etc. are widely cancelled if they are not absolutely necessary. The result is a higher contractor/projects ratio. Bigger civil engineering firms that lose out on the few bids available in their class suddenly become hawkish and encroach on the projects small civil engineering firms would normally take, putting them in more danger of shutting down. This makes firms focus a lot on their competitors as a means of survival as in strategic conflict theory. A small firm for example will do anything to know how much its competitor has put in for a bid and will want to beat it all cost, even if it is at a minor loss, with the hope of repeat business and starving the competitor to death. One potential major solution is to continuously seek proper information (Marcella and Illingworth, 2012) as there are usually hints about such events (economic recession), then create a strategic plan. With this, owners can proactively take decisive actions e.g. closing firm down early before any losses in the worst case.

On 'immigration', the challenge highlighted by interview respondents was the open EU border that allows people from other EU countries to work unrestrictedly in the UK. The major complaint was that some probably unregistered skilled workers were able to take especially small renovation and refurbishment jobs for unrealistically low prices. On the other hand, cheap construction labour immigrants favour big civil engineering firms as employing or contracting them helps reduce their cost/wages (Beaverstock and Hall, 2012; Rolfe et al., 2013). The 
immigration problem is somewhat similar to that of 'too many new firms springing up' as they both represent threat of new entrants. When there is no barrier to entry, as is the case in the construction industry, and anyone or any firm can just decide to start or stop construction works, then the market can easily be over flooded with firms, leading to tipped balances, fierce competition and insolvencies (BurtonShaw-Gunn, 2009; De Valence, 2012; Research and Markets, 2015). Using strategy as ploy to distract or deter competitors, for example reporting unregistered workers who avoid tax might increase likelihood of survival.

'Burden of sustainable construction practice', seem to be a controversial criterion because it was highlighted according to the analysis here and some other studies (e.g. Carmichael and Balatbat, 2009) as being a major insolvency driver while many other studies (Orlitzky et al., 2003; Dorfleitner and Utz, 2012; Siew et al., 2013) have claimed that sustainability increases profitability. The claims that green buildings do pay for themselves in the long run in itself is a testament to them being more expensive initially. The sustainability issue might even be more challenging with smaller firms when clients seek a more environment friendly way of execution and want to pay less, as experienced by most respondents that spoke about this criterion. The issue is because there are many desperate construction firms who are starved of jobs, the threat of substitution is critically high hence the client can make ridiculous offers. Also because the jobs on offer can be executed by many firms as most firms do not offer anything unique, then extreme competitive rivalry sets in and firms put in unrealistic deals for requests like more expensive sustainable construction. Further, as firms try to establish special relationship with clients and ensure repeat business in a market with high contractor/client ratio, they go that harmful extra length to please the client, resulting in considerable buyer (client) power (Betts and Ofori, 1992) which allows clients to drive down bid prices. 
Competence-based management: Quality and quantity of available resources is very important to firms. Quality is especially important for the small firms as they always have few resources. The resource quality issue has to do with the organization competency-based management theory which according to Sanchez (2004), the resource competence is a key aspect of (organization competences). The theory is defined by Sanchez (2004) as "the ability to sustain the coordinated deployment of assets in ways that help a firm achieve its goals" ( $\mathrm{p}$. 521). The two key insolvency criteria (i.e. retention of quality staff and management/owner characteristics) identified under this factor in this study are human resource based criteria. Finding out that quality resource can help avoid insolvency is in line with Barney's (1991) study where he noted that the resources of a firm can be the main cause/driver of continued competitive advantage as the resources empower the firm to apply strategies that boost effectiveness and efficiency.

'Retention of quality staff' as a reason for insolvency was linked directly to firm size (Kale and Arditi, 1999) and immigrants by respondents. Quality staff that are immigrants generally do not mind to work with small civil engineering firms when they have visa restrictions but once they get better offers with potential sponsorship from bigger firms, they switch. The challenge is that most small civil engineering firms position themselves strategically (Strategy as Position) as low wage payers with little benefit. With bigger firms offering trainings, mentoring to professional membership, golden hello, access to state of the art equipment and software among others benefits, small firms need to position themselves in a way that can offer some kind of present and future benefits beyond just wages if quality staff are to be retained. Though positional strategy is usually decided based on clients, it is equally important to position a firm to keep quality staff if the firm is to gain any competitive advantage, required to avoid insolvency, in terms of services offered. This is the case of resource (a quality staff in this case) 
leading to position (Korn and Pine, 2014) although, the positional view is always seen in contrast to the resource based view strategy (Barney, 1991).

There are various characteristics of a small civil engineering firm's management team, chief executive officer (CEO), president or owner that have adverse effects on its survival. These include unfounded optimism, taking unworthy risks with large construction projects, autocracy, a person holding multiple executive positions, etc. (Pearce and Zahra, 1991; Abidali and Harris, 1995; Daily and Johnson, 1997). The most damaging of all is autocracy as it is a common feature of failed construction firms (Hall 1994; Abidali and Harris, 1995) and was common to some of the respondents as they used the word 'I' frequently. From their stories, most decision were taken just by them without input from other staff members. Unfounded optimism has also been identified as a major cause of insolvency by Ucbasaran et al. (2009). The inertia of a construction company's owner/management leads to not realising the available opportunities and threats to the business (Gilbert, 2005). When business is slow, a construction firm specialized in pile foundation installation, for example, should be able to identify opportunities of excavation projects and use its excavators for executing such projects. Most management/owner characteristics are a case of strategy as perspective as this relies heavily on patterns of thinking. A quality, intelligent and experienced management/owner for example, will be able to consistently think of alternatives when works in the firm's area of specialty are unavailable. This then in turn becomes the pattern and strategy of the firm.

Operations efficiency and other management issues: The problem of 'collecting receivables' is a big one for small civil engineering firms (Arditi, et al., 2000) and leads the line in this factor. From the stories of respondents, it appears collecting payment for work done has been a 'pain in the neck' for small civil engineering firms. A potential solution might be to take the strategy as pattern approach, where the pattern of happenings in a firm is checked, then what is 
has led to quick collection of receivables in the past is retained and ferocious effort is made to dumping elements that have led otherwise.

Buying unnecessary equipment is usually a case where a small civil engineering firm seeks to improve itself by buying some high level equipment. This leads to increased company overheads which is normally needed during growth. The problem however sets in when the equipment (or software, tool etc.) gets rarely used/needed and consequently does not bring value, yet bring about significant maintenance expenses. This is sometimes as a result of the cyclical construction market or wrong projections where a firm, based on maybe the last three projects executed, wrongly deems a particular expensive equipment (or software, tool etc.) useful as it envisages winning many similar projects (unfounded optimism). Sadly, these expenses are quite hard to remove, forcing a firm to become slave to its overhead, and inevitably leading to losses (Schleifer et al. 2014)

Information management: 'Start-up reason/poor planning' is the most important under this factor. Numerous respondents expressed regret on either seeking information from the wrong sources, or not seeking enough information, before starting the firm. Their poor strategy as plan clearly contributed to their insolvency as also found in other studies (e.g. Hall, 1994; Marcella and Illingworth, 2012). It appeared the unfortunate assumption that as a consumer, it should be easy to make the consumed product had set in in some cases as indicated by one respondent.

The case of 'isolation/networking' is that of not having the right information about where to go when there is a problem. Networking from early stage is very vital to the survival to any small firm as already established by Deakins and Freel (1998). The isolation complaint is a testament to the poor information gathering culture of small civil engineering firms as there are many bodies/networks that any small firm or small civil engineering firms can join (e.g. Federation 
of Small Businesses or Construction Excellence respectively). Isolation would not bode well for competitive rivalry as it becomes hard to compete against other small civil engineering firms that boast proper networking and enjoy various benefits. A firm with Federation of Small Businesses for instance, might get the body's technical, financial, resource, mental and legal support in a legal conflict arising from a contract thereby boosting his chances of winning.

\subsection{Conclusion}

This study focuses on uncovering the main factors that lead to insolvency of small civil engineering firms using mixed method. Story telling method was used to obtain qualitative data which was analysed with narrative and thematic analysis. The resulting themes were used to create insolvency criteria which were in turn used to form a questionnaire. The questionnaire responses were analysed using reliability analysis, relevance index score and factor analysis. The results showed that the five most relevant criteria include economic recession, immigration, too many new firms springing up, collecting receivables and burden of sustainable construction practice in that order. The four underlying factors established through factor analysis are: market forces, competence-based management, operations efficiency and other management issues and information management.

Though predictable, it can be deduced from the results that factors affecting big and small civil engineering firms can be quite different and sometimes, even opposite. More studies should hence focus on small civil engineering firms if the insolvency tide in the construction industry is to be stemmed since over $96 \%$ of UK civil engineering firms are small or micro in size. Further, the top three most relevant criteria from the relevance index score are of the market forces factor, showing that the main reasons for insolvency are not usually directly influenceable by the affected small civil engineering firms. The key solution is therefore to be prepared 
for the worst by always sourcing the right information and using strategy as plan among other strategies. It can be concluded from the discussion section that the implementation of most of the elements of Mintzberg's five Ps of strategy and/or Porter's five competitive forces can help to avert insolvency of small civil engineering firms.

The practical implication of this research is mainly in the unique resource it provides for potential and current owners of small and micro civil engineering firms. They can definitely get some knowledge on what strategies to implement to avoid insolvency from this study. The contribution to knowledge here is the presentation of criteria that can serve as variables for developing insolvency prediction models for small civil engineering firms (IPMCEF). Also, the criteria/factors presented in this study can be used to develop a theory to be tested in future studies. The limitation of this work is that data was not collected from owners/managers of existing firms. Care should thus be taken in implementing the findings because there is no other evidence that relates them to insolvency of small CEFs apart from the fact that they are reported and ranked by owners/managers of failed S\&M CEFs. Future studies should carry out more inductive works, and endeavour to include owners/managers of existing S\&M CEFs in their study, to establish many more criteria; this will make it possible to correlate the criteria (variables) to insolvency, develop regression models, and develop IPMCEF. Future studies should also make effort to establish factors differentiating good and bad CEFs in good and bad economic environment.

\section{References}

Abidali, A.F. and Harris, F. (1995). A methodology for predicting failure in the construction industry. Construction Management and Economics, 13 (3), pp. 189-196.

Andrews, K.R. (1971). Concepts of Corporate Strategy. Homewood: Richard D. Irwin. 
Arditi, D., Koksal, A. and Kale, S. (2000). Business failures in the construction industry. Engineering, Construction and Architectural Management, 7 (2), pp. 120-132

Bal, J., Cheung, Y. and Wu, H. (2013). Entropy for business failure prediction: an improved prediction model for the construction industry, Advances in Decision Sciences, 2013, pp. $1-14$

Balcaen and Ooghe (2006). 35 years of studies on business failure: an overview of the classic statistical methodologies and their related problems. The British Accounting Review, 38 (1) pp. 63-93

Barney, J. (1991). Firm resources and sustained competitive advantage. Journal of management, 17 (1), pp. 99-120.

Betts, M. and Ofori, G. (1992). Strategic planning for competitive advantage in construction. Construction Management and Economics, 10 (6), pp. 511-32.

Betts, M. and Ofori, G. (1993). Competitive advantage in construction: reply. Construction Management and Economics, 11 (1), pp. 73-4.

Budayan, C., Dikmen, I. and Birgonul, M.T. (2013). Investigation of drivers and modes of differentiation in Turkish construction industry. Engineering, Construction and Architectural Management, 20 (4), pp. 345-64.

BurtonShaw-Gunn, S. A. (2009). Risk and financial management in construction. Surrey: Gower Publishing, Ltd.

Beaverstock, J. V., and Hall, S. (2012). Competing for talent: global mobility, immigration and the City of London's labour market. Cambridge Journal of Regions, Economy and Society, 5 (2012), pp. 271-287.

Bouwen, R., and Steyaert, C. (1997). Telling Stories of Entrepreneurship. Towards a narrative-contextual epistemology for entrepreneurial studies. In R. Donckels and A. Mietten (Eds.),Entrepreneurship and SME research (pp. 47-62). Aldershot, UK: Ashgate.

Carmichael, D.G. and Balatbat, M.C.A. (2009), "Sustainability on construction projects as a business opportunity”, SSEE 2009 International Conference, Solutions for a Sustainable 
Planet, Society for Sustainability and Environmental Engineering, Engineers Australia, Melbourne, 23-24 November.

Chen, J. H. (2012). Developing SFNN models to predict financial distress of construction companies. Expert Systems with Applications, 39 (2012), pp. 823-827

Child, D. (2006). The essentials of factor analysis, 3rd ed. London: Continuum International Publishing.

Chinowsky, P. S., and Meredith, J. E. (2000). Strategic management in construction. Journal of Construction Engineering and Management, 126 (1), pp. 1-9.

Daily, C.M. and Johnson, J.L. (1997). Sources of CEO power and firm financial performance: A longitudinal assessment. Journal of Management, 23 (2), pp. 97-117.

Daily Mail Reporter (2012). Building gloom hits economy as more than 1,500 construction firms close this year. Daily Mail: This is Money, 30 July 2012.

De Valence, G. (2012). The Significance of Barriers to Entry in the Construction Industry. Construction Economics and Building, 7 (1), pp.29-36.

Deakins, D., and Freel, M. (1998). Entrepreneurial learning and the growth process in SMEs. The Learning Organization, 5 (3), pp. 144-155.

Denning, S. (2005). The role of narrative in organizations. In J.S. Brown, S. Denning, K. Groh and L. Prusack (Eds.), Storytelling in organizations: why storytelling is transforming 21st century organizations and management (pp. 165-182). Oxford: Elsevier Butterworth-Heinemann.

Department for Business Innovation and Skills (2015). Statistical Release: Business Population Estimates for the UK and regions 2015. National Statistics, URN 15/92

Dikmen, I., and Birgönül, M. T. (2003). Strategic perspective of Turkish construction companies. Journal of Management in Engineering, 19 (1), pp. 33-40.

Dorfleitner, G. and Utz, S. (2012). Safety first portfolio choice based on financial and sustainability returns. European Journal of Operational Research, 221 (1), pp. 155164.

Field, A. (2005). Discovering Statistics using SPSS, 3rd edition. London: Sage Publications. 
Gabriel, Y. and Griffiths, D.S. (2004) 'Stories in Organizational Research', in C. Cassell and G. Symon (eds) Essential Guide to Qualitative Methods and Analysis in Organizational Research. London: Sage, pp. 114-126.

Gilbert, C.G. (2005). Unbundling the structure of inertia: Resource versus routine rigidity. Academy of Management Journal, 48 (5), pp. 741-763.

Hall, G. (1994). Factors distinguishing survivors from failures amongst small firms in the UK construction sector. Journal of Management Studies, 31 (5), pp. 737-760.

Harada, N. (2007). Which firms exit and why? An analysis of small firm exits in Japan. Small Business Economics, 29 (4), pp. 401-414.

Hill, J., and McGowan, P. (1999). Small business and enterprise development: questions about research methodology. International Journal of Entrepreneurial Behavior and Research, 5 (1), pp. 5-18.

Jaunzens, D. (2001). Influencing small businesses in the construction sector through research. BRE Informing and Influencing Small to Medium Enterprises.

Kale, S. and Arditi, D. (1999). Age-dependent business failures in the US construction industry. Construction Management and Economics, 17 (4), pp. 493-503.

Kometa, S.T., Olomolaiye, P.O., Harris, F.C. (1994). Attribute of UK construction clients influencing project consultants' performance. Construction Management and Economics, 12 (5), pp. 433-443.

Korn, K.C. and Pine, B.J. (2014). The Laws of Managing. Indianapolis: Dog ear publishing

Li, B., Akintoye, A., Edwards, P.J., Hardcastle, C. (2005). Critical success factors for PPP/PFI projects in the UK construction industry. Construction Management and Economics $\mathbf{2 3}$ (5), pp. 459-471.

Marcella, R., and Illingworth, L. (2012). The impact of information behaviour on small business failure. Information research, 17 (3).

Mintzberg, H., Ahlstrand, B. W., Ahlstrand, B., and Lampel, J. (1998). Strategy Safari: A Guided Tour Through The Wilds of Strategic Mangament. New York: Free Press 
Moore, K. (2011). Porter or Mintzberg: Whose View of Strategy Is the Most Relevant Today? Available at http://www.forbes.com/sites/karlmoore/2011/03/28/porter-or-mintzbergwhose-view-of-strategy-is-the-most-relevant-today/\#59ace6e56e36 [Accessed on $23 / 01 / 206]$

Orlitzky, M., Schmidt, F. L., and Rynes, S. L. (2003). Corporate social and financial performance: A meta-analysis. Organization studies, 24(3), 403-441.

Oyedele, L. O. (2013). Analysis of architects' demotivating factors in design firms. International Journal of Project Management, 31 (3), pp. 342-354.

Pallant, J. (2005). SPSS Survival Manual, 2nd edition. Berkshire: Open University Press.

Rae, D. (2000). Understanding entrepreneurial learning: a question of how?.International Journal of Entrepreneurial Behavior and Research, 6(3), 145-159.

Research and Markets (2015). US Construction Industry - Porter's Five Forces Strategy Analysis. Dublin: Research and Markets

Rolfe, H., Rienzo, C., Lalani, M., and Portes, J. (2013). Migration and productivity: employers' practices, public attitudes and statistical evidence.

Rumelt, R. P., Schendel, D., and Teece, D. J. (1991). Strategic management and economics. Strategic management journal, 12 (S2), pp. 5-29.

Sanchez, R. (2004). Understanding competence-based management: Identifying and managing five modes of competence. Journal of Business research, 57 (5), pp. 518-532.

Schleifer, T. C., Sullivan, K. T., \& Murdough, J. M. (2014). Managing the Profitable Construction Business: The Contractor's Guide to Success and Survival Strategies. New Jersey: John Wiley \& Sons.

Schelling, T. (1963). The Strategy of Conflict. New York: A Galaxy Book, Oxford University Press

Shapiro, C. (1989). The theory of business strategy. The Rand journal of economics, 20 (1), pp. $125-137$.

Shotter, J. (1993). Conversational Realities: Constructing Life through Language, London: Sage. 
Siew, R. Y., Balatbat, M. C., and Carmichael, D. G. (2013). The relationship between sustainability practices and financial performance of construction companies. Smart and Sustainable Built Environment, 2 (1), pp. 6-27.

Simon, H. A. (1957). Models of Man: Social and Rational. New York: Wiley.

Stanworth, J. and Purdy, D. (2008) SME Facts and Issues: A Compilation of Current Data and Issues on U.K. Small and Medium-sized Firms. United Kingdom: Small Enterprise Research Team

Stokes, D., and Blackburn, R. (2002). Learning the hard way: the lessons of owner-managers who have closed their businesses. Journal of small business and enterprise development, 9 (1), pp. 17-27.

Tansey, P., Spillane, J. P., and Meng, X. (2014). Linking response strategies adopted by construction firms during the 2007 economic recession to Porter's generic strategies. Construction Management and Economics, 32(7-8), 705-724.

Ucbasaran, D., Westhead, P., Wright, M., and Flores, M. (2010). The nature of entrepreneurial experience, business failure and comparative optimism. Journal of Business Venturing, 25 (6), pp. 541-555.

Wood, M. (2015). Insolvency Statistics - April to June 2015 (Q2 2015). London: The Insolvency Service. 
Table 1: Demographics of the respondents and the firms

\begin{tabular}{|l|l|l|l|}
\hline Respondent Type & $\begin{array}{l}\text { Number of } \\
\text { respondents }\end{array}$ & $\begin{array}{l}\text { No. of years that } \\
\text { insolvent firm(s) } \\
\text { operated for }\end{array}$ & $\begin{array}{l}\text { No of owner } \\
\text { respondents } \\
\text { currently } \\
\text { another firm }\end{array}$ \\
\hline \multirow{3}{*}{ Owner } & 4 & $1-2$ & 4 \\
\cline { 2 - 4 } & 2 & $3-4$ & 1 \\
\cline { 2 - 4 } & 5 & $5-6$ & 5 \\
\cline { 2 - 5 } & 1 & $7-10$ & 1 \\
\hline \multirow{2}{*}{$\begin{array}{l}\text { Managerial } \\
\text { employee }\end{array}$} & 4 & $10-15$ & 2 \\
\hline Total level & 1 & $5-6(5)^{*}$ & - \\
\cline { 2 - 5 } & 1 & $7-10(9)^{*}$ & \\
\hline
\end{tabular}

*Figures in parenthesis represent the number of years the managerial level employee spent with the firm 
Table 2: Example of coding from priori and new themes and the respondents' statements they are taken from

\begin{tabular}{|l|l|l|}
\hline \multicolumn{1}{|c|}{ Prior } & \multicolumn{1}{|c|}{ New } & \multicolumn{1}{c|}{ Statements } \\
\hline $\begin{array}{l}\text { New entrants } \\
\text { threats (Porters } \\
\text { theory) }\end{array}$ & $\begin{array}{l}\text { Collection of } \\
\text { receivables } \\
\text { 'The works dried out because people now prefer to give the } \\
\text { jobs to some European immigrants that will do a shoddy job } \\
\text { for a token' }\end{array}$ \\
\hline $\begin{array}{l}\text { Construction is very interesting. You bring your stuff and } \\
\text { workers in, get the job done and get paid. Easy money... But } \\
\text { I stopped because people don't pay up. You make several } \\
\text { fruitless efforts that even cost you money. }\end{array}$ \\
\hline $\begin{array}{l}\text { Conflict } \\
\text { management } \\
\text { capability }\end{array}$ & $\begin{array}{l}\text { Legal cost } \\
\text { you to court if you dismantle the job despite you will incur } \\
\text { losses on that. }\end{array}$ \\
\hline $\begin{array}{l}\text { Sustainability } \\
\text { issue }\end{array}$ & $\begin{array}{l}\text { Over reliance } \\
\text { on accounting } \\
\text { books to make } \\
\text { decision }\end{array}$ & $\begin{array}{l}\text { We made took our time and always consulted our books before } \\
\text { making decisions. In fact, we ensured almost no financial } \\
\text { decision was taken without checking our account books }\end{array}$ \\
\hline $\begin{array}{l}\text { Strategy } \\
\text { plan } \\
\text { (Mintzberg's } 5 \\
\text { Ps), Economic } \\
\text { recession }\end{array}$ & $\begin{array}{l}\text { Many people don't know what they want. They want you to } \\
\text { use only environmental friendly stuff for them yet they } \\
\text { also want the cheapest price. They want to get what they } \\
\text { don't want to pay for }\end{array}$ \\
\hline & $\begin{array}{l}\text { I understand property investment and always buy houses and } \\
\text { lands and sell them later. Brother, this brings more money to } \\
\text { do the building [i.e. construction]. The stupid problem with } \\
\text { economy [recession] caused all my property to go down } \\
\text { [i.e. devalue]. Brother, why is America problem our problem } \\
\text { (hisses). }\end{array}$ \\
\hline
\end{tabular}


Table 3: The final 17 insolvency criteria and associated statistical analysis.

\begin{tabular}{|l|l|c|c|c|c|}
\hline & \multicolumn{1}{|c|}{ Insolvency Criteria } & \multicolumn{2}{c|}{$\begin{array}{c}\text { Reliability } \\
\text { Analysis }^{\mathbf{a}}\end{array}$} & \multicolumn{2}{c|}{$\begin{array}{c}\text { Insolvency Criteria Relevance } \\
\text { Index (ICRI) and Ranking }\end{array}$} \\
\hline & & $\begin{array}{c}\text { Cronbach Alpha } \\
\text { if Item Deleted }\end{array}$ & ICRI & $\begin{array}{c}\text { In-group } \\
\text { Ranking }\end{array}$ & $\begin{array}{c}\text { Overall } \\
\text { ranking }\end{array}$ \\
\hline & Internal issues related criteria & & & \\
\hline IC1 & Collecting receivables & 0.839 & 81.1 & 1 & 5 \\
\hline IC2 & Retention of quality staff & 0.823 & 77.0 & 2 & 7 \\
\hline IC3 & Management/Owner Characteristics & 0.808 & 74.0 & 3 & 8 \\
\hline IC4 & Bidding problems & 0.863 & 67.6 & 4 & 9 \\
\hline IC5 & Outsourcing account management & 0.852 & 67.1 & 5 & 10 \\
\hline IC6 & Start-up reason/Poor planning & 0.846 & 52.9 & 6 & 11 \\
\hline IC7 & Conflict management struggles & 0.787 & 52.6 & 7 & 12 \\
\hline IC8 & Isolation/networking & 0.804 & 50.3 & 8 & 13 \\
\hline IC9 & Over reliance on account statement & 0.860 & 48.0 & 9 & 14 \\
\hline IC10 & Buying unnecessary equipment & 0.686 & 44.6 & 10 & 15 \\
\hline & External issues related criteria & & & & \\
\hline IC11 & Economic recession & 0.836 & 90.1 & 1 & 1 \\
\hline IC12 & Fluctuation of construction materials cost & 0.870 & 89.7 & 2 & 2 \\
\hline IC13 & Immigration & 0.833 & 88.5 & 3 & 3 \\
\hline IC14 & Too many new firms springing up & 0.811 & 81.6 & 4 & 4 \\
\hline IC15 & Burden of sustainable construction practice & 0.786 & 80.0 & 5 & 6 \\
\hline IC16 & Skill of workforce & 0.778 & 44.4 & 6 & 16 \\
\hline IC17 & Low attractiveness to quality staff & 0.772 & 43.0 & 7 & 17 \\
\hline
\end{tabular}

${ }^{\text {a }}$ Overall Cronbach's alpha $=0.868$ 
Table 4: Exploratory factor analysis.

\begin{tabular}{|l|l|c|c|c|}
\hline & & Eigen Value & $\begin{array}{l}\text { Percentage of } \\
\text { variance }\end{array}$ & $\begin{array}{l}\text { Factor } \\
\text { loadings }\end{array}$ \\
\hline & Market forces & 5.125 & 30.149 & \\
\hline IC11 & Economic recession & & & 0.909 \\
\hline IC12 & Fluctuation of construction materials cost & & & 0.816 \\
\hline IC13 & Immigration & & & 0.806 \\
\hline IC14 & Too many new firms springing up & & & 0.618 \\
\hline IC15 & Burden of sustainable construction practice & & & 0.436 \\
\hline & Competence-based management & 3.465 & 20.385 & \\
\hline IC2 & Retention of quality staff & & & 0.869 \\
\hline IC3 & Management/Owner Characteristics & & & 0.864 \\
\hline IC7 & Conflict management struggles & & & 0.852 \\
\hline IC16 & Skill of workforce & & & 0.662 \\
\hline IC17 & Low attractiveness to quality staff & & & 0.479 \\
\hline & $\begin{array}{l}\text { Operations efficiency and other } \\
\text { management issues }\end{array}$ & 2.506 & 14.742 & \\
\hline IC1 & Collecting receivables & & & 0.889 \\
\hline IC10 & Buying unnecessary equipment & & & 0.848 \\
\hline IC4 & Bidding problems & & & 0.696 \\
\hline IC5 & Outsourcing account management & & & 0.201 \\
\hline & Information management & & \\
\hline IC6 & Start-up reason/Poor planning & & & 0.653 \\
\hline IC8 & Isolation/networking & & & 0.273 \\
\hline IC9 & Over reliance on account statement & & \\
\hline & & & & \\
\hline
\end{tabular}

Note: Criteria in italics are not considered as explained in this section 